\title{
$\mathrm{RS}$ 를 이용한 홍수범람지역 탐지 정보화 기법 연구*
}

\author{
신형진 $^{1} \cdot$ 채효석 $^{1 \%} \cdot$ 황의호 $^{1} \cdot$ 박재영 $^{2}$
}

\section{A Study of Informationization Technique for Detecting Flood Inundation Area Using RS*}

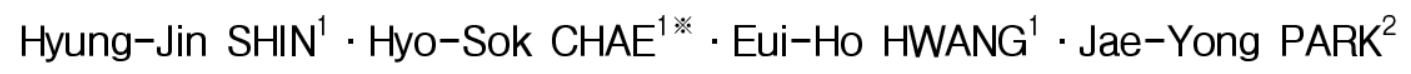

\section{요 약}

2011년 태국 짜오프라야 강 유역에서 발생한 홍수에 의해 많은 피해가 발생했다. 본 연구에서 는 홍수범람시 시공간적 침수상황이 파악 가능한 Terra MODIS 영상을 이용하여 태국 짜오프라 야 강 유역의 홍수에 의한 침수지역을 추정하였다. 2011년 7월 29일에서 2012년 1월 9일까지 의 $500 \mathrm{~m}$ 해상도인 MODIS product MOD09 8일 합성 영상을 수집하고 식생지수(EVI), 지표수 분지수(LSWI) 와 DVEL지수(식생지수와 지표수분지수의 차이)를 이용하여 홍수범람 지역과 수 역관련 지역의 탐지 기법을 제시하였다. 본 연구의 결과는 홍수 범람지역의 자료를 정보화하고 그 결과를 정량적으로 제시하는 방법으로 활용될 수 있으며, MODIS 자료의 이용은 시공간적 하 천 홍수범람지역 탐지의 가능성을 알 수 있었다.

주요어 : Terra MODIS, 식생지수, 지표수분지수, 홍수범람지역, 태국

\section{ABSTRACT}

In 2011, floods were at the worst stage of devastation in Chao Phraya river basin of Thailand. The purpose of this study is to trace the flood inundation area around Chao Phraya river basin by using Terra MODIS image because it has the ability of spatiotemporal dynamics. The MODIS indices, which included the enhanced vegetation index(EVI), land surface water index(LSWI), and the difference in the values of EVI and LSWI(DVEL), were extracted from MODIS product MOD09 8-day composite datasets with a spatial resolution of 500m from Jul. 29, 2011 to Jan. 09, 2012. We found that combined application of EVI, LSWI, and DVEL was suitable for monitoring

2012년 1월 30일 접수 Received on January 30, 2012 / 2012년 3월 8일 수정 Revised on March 8, 2012 / 2012년 3월 15일 심사완료 Accepted on March 15, 2012

* 본 연구는 국토해양부 건설기술혁신사업의 연구비지원(11기술혁신C06)에 의해 수행되었음.

1 한국수자원공사 $\mathrm{K}$-water연구원 수자원연구소 $\mathrm{K}$-Water Institute, Korea Water Resources Corporation

2 한국수자원공사 조사기획처 Dept. of Water Resources Investigation \& Planning, Korea Water Resources Corporation

※ 연락저자 E-mail : hyosok@kwater.or.kr 
flood inundation. For the extracted flood inundation area and water-related area. The result can be used to acquire the flood inundation data scattered and demonstrate the potential for the use of MODIS data for temporal and spatial detection of flood effects.

\section{KEYWORDS : Terra MODIS, EVI, LSWI, Flood Inundation Area, Thai}

\section{서 론}

기후변화에 따른 지진, 폭설, 홍수 등의 자 연재해가 갈수록 빈번해질 뿐만 아니라 규모 또한 커지고 있다. 특히 이상기후에 의한 국 지강우, 태풍, 홍수에 의한 침수피해가 늘어나 고 있다. 홍수피해지역 파악은 그 예방대책의 수립과 더불어 피해복구사업의 신속한 시행을 위해서도 정확한 현장조사가 필요하다. 그러 나 홍수에 의한 피해지역이 광범위하고 피해 실태를 현장조사를 통해 파악하기에는 한계가 따른다(이미선 등, 2006). 인공위성 영상을 활용한 원격탐사 기법은 홍수, 폭설, 가뭄, 산 불 등 광역 규모의 다양한 자연재해에 대한 자료를 획득할 수 있기 때문에 실측자료의 시 공간적 한계를 극복하기 위해 많이 사용되고 있다. 특히 광범위한 지역을 대상으로 하는 경우 인공위성자료의 이용은 대단히 유용하다 (신사철과 유철상, 1997). 홍수와 같은 재해 발생 시 홍수발생 지역에 대한 매핑, 모니터 링 및 재해지역 관리 등에 있어 매우 유용한 정보를 제공할 수 있다(채효석, 2005).

국내에서도 Landsat TM/ETM+, RADARSAT SAR, Terra MODIS 등 다양한 위성영상들을 이용하여 재해관련 연구가 시도 되고 있다. 박병욱과 김철(1997)은 홍수 전 후의 Landsat TM 영상자료를 이용하여 유실 된 농지 및 침수흔적을 분석하였고, 이규성 등 (2000)은 시계열 RADARSAT영상을 이용 하여 경기도 북부지역을 대상으로 홍수침수 피해지역을 효과적으로 파악하였으며, 채효석 (2005)은 2000년 태국 메콩 강 유역의 Tonle Sap 호에서 발생한 홍수 피해에 대해
Landsat ETM+와 RADARSAT SAR 영상을 이용하여 범람년적을 분석하고 더 정확한 면 적 분석을 위해 cost-distance 기법을 이용 하여 홍수범람 면적을 분석하였다(채효석, 2005). 그리고 이미선 등(2006)은 RADARSAT SAR 영상을 이용하여 농촌유역 의 홍수에 의한 침수지역을 추정하였다.

인공위성 원격탐사 센서 중 MODIS 자료는 중위도 지방에서 하루 최대 4 회 정도 획득이 가능한 높은 시간주기성과 $250,500,1000$ $\mathrm{m}$ 의 다양한 공간해상도, 그리고 36 개 밴드에 달하는 다중분광자료를 제공하기 때문에 지표 와 대기 하층에서 발생하는 전지구적인 자연 재해를 연속적으로 감시할 수 있는 장점이 있 다. 이 때문에 최근 MODIS 위성 자료를 기반 으로 지역 또는 지구규모의 다양한 자연재해 와 이에 관련된 많은 연구들이 활발히 진행되 고 있다. 박정술 등(2006)은 MODIS NDVI 와 LSWI를 이용하여 봄 가뭄 지역을 추출하 였으며, 정승택 등(2011)은 MODIS 식생지수 와 지표수분지수를 이용하여 논의 관개시기인 담수상태에 대해서 Xiao et al.(2005)의 담수 지역 추출 알고리즘을 적용하고 평가하였다. Zhan et al.(2002)은 MODIS Level 1B 자 료를 이용해 Vegetation Cover Conversion 알고리듬으로 캄보디아의 2000년 홍수범람 지역을 성공적으로 탐지하였으며, Xiao et al. (2005)은 중국 남부지역의 넓은 논 지역에 대해 식생지수와 지표수분지수를 이용하여 관 개시기 탐지 알고리즘을 개발하였는데 이는 논 지역의 수분 상태를 추출하는 알고리즘으 로서 토지피복 중 담수지역 추출기법을 제시 하였다. Sakamoto et al.(2007)은 MODIS 자료를 이용하여 캄보디아와 베트남에 걸쳐있 
는 MeKong Delta 지역의 시계열 홍수범람 지역 추출 기법을 제시하였다. 최근 Yan et al. (2010)은 MODIS 시계열 자료를 이용하여 갯벌 홍수의 시공간변화를 탐지하였다.

태국 홍수는 2011년 7월 말부터 3개월간 내린 집중호우로 중부지방에 50년 만에 최악 의 자연재해가 발생하였다. 태국 북쪽 지역에 서 난 강과 핑 강의 범람을 시작으로 태국 중 앙 지역을 흐르는 짜오프라야 강의 수위는 상 류의 홍수가 하류로 내려옴에 따라 범람하여 수도 방콕까지 침수되었다.

따라서 본 연구에서는 태국의 홍수 범람 유 역인 짜오프라야 강 유역을 대상으로 Xiao et al.(2005) 과 Sakamoto et al.(2007)에 의해 제안된 식생지수인 $\mathrm{EVI}$ 와 지표수분지수인 LSWI를 이용한 홍수범람지역 탐지 알고리듬 을 개선하고 짜오프라야 강의 홍수범람지역 추출할 수 있는 적정 임계값을 분석하여 Terra MODIS 위성영상을 이용하여 짜오프 라야 강 유역의 홍수범람지역 탐지 기법을 제 시하고, 2011년 태국 홍수범람 지역을 추정 함으로써 침수피해지역의 공간적 범위를 분석
하고자 하였다.

\section{대상유역}

본 연구의 대상유역은 2011년 7월 말부터 3 개월간 내린 집중호우에 의한 대홍수로 침수 가 일어난 태국 짜오프라야 강 유역으로, 짜 오프라야 강은 태국 북부 산지에서 발원하여 서쪽의 핑 강과 동쪽의 난 강이 합류해 태국 중앙지역을 흐르며 태국 최고의 곡창지대와 수도 방콕을 관통하는 중요한 유역이다(그림 $1)$. 짜오프라야 강 전체 길이는 $1,200 \mathrm{~km}$, 유 역년적은 $160,813 \mathrm{~km}$ 이고, 고도는 $0 \sim 2801 \mathrm{~m}$ 로 북쪽의 고도가 높아 급경사를 이룬다. 침 수가 일어난 지역의 고도는 약 $285 \mathrm{~m}$ 이하로 대부분이 논 지역으로 평평한 평야이다(그림 1). 세계일보에 따르면 홍수에 의한 침수 수 위가 최대 $2 \mathrm{~m}$ 에 이르렀으며, 태국 76 개주 중 27 개주가 침수되었고 80 만 채의 건물파괴와 이재민 113,000 명, 침수면적 162 억 $\mathrm{m}^{2}$ 사망자 가 381 명, 손해액 5,000억 바트(18조3350억 원)에 이르는 피해를 일으켰다.

태국 기상청에 따르면 계절성 몬순 기후와

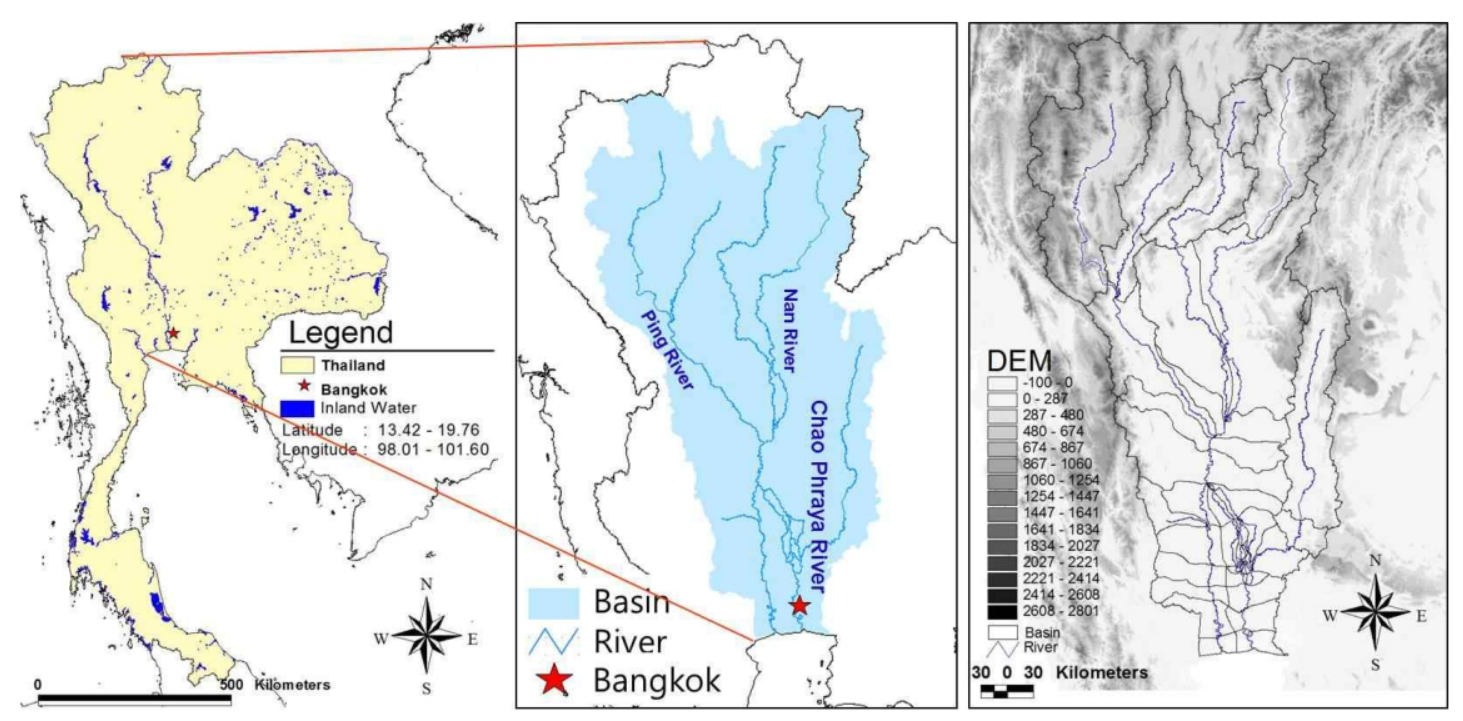

FIGURE 1. 연구대상 유역 


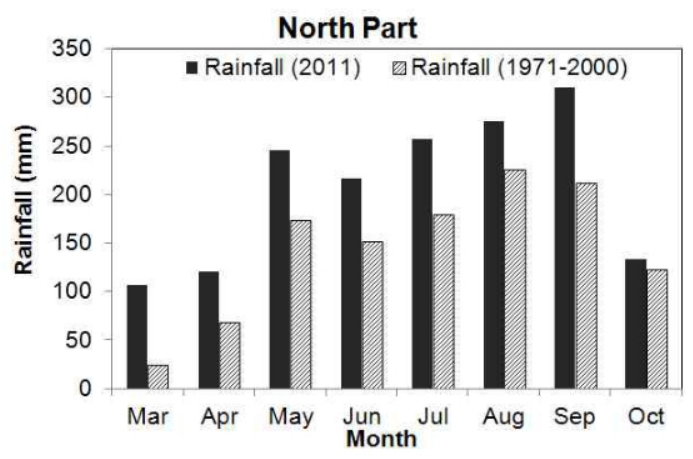

(a) North part

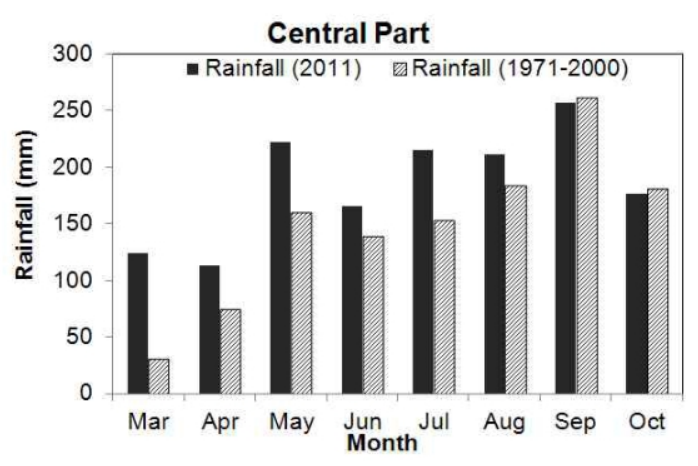

(b) Central part

FIGURE 2. 홍수 범람 유역의 2011년 월강수량 $(\mathrm{mm}), 30$ 년 (1971-2000) 월강수량 $(\mathrm{mm})$

열대저기압의 영향으로 태국의 30년(1971 2000, 1월 10월) 연강수량은 $1,423 \mathrm{~mm}$ 이나 2011년 (1월 10월)의 총강수량은 $1,822 \mathrm{~mm}$ 로 약 $28 \%$ 강수가 더 많이 내렸으며 특히 9 월에 집중호우가 지속되었다. 그림 2와 같이 3 월부터 8월까지 과거 30년보다 강수가 더 많 이 내린 것을 확인할 수 있다. 북쪽지역은 5 월 에서 10월까지 과거 30년 강수량보다 2011년 에 20 60\% 증가하였고, 수도 방콕이 있는 중 앙지역은 10 40\% 강수량이 증가하였다.

\section{Terra MODIS 시계열 자료}

MODIS (Moderate-Resolution Imaging Spectroradiometer)는 지구 생물권 활동에 관한 자료를 제공하는 미항공우주국 Terra EOS(Earth Observation system) 위성의 주 센서로 해양, 육상과 대기 분야에 적용이 가
능한 다목적 센서이다. MODIS는 현재 36개 의 밴드를 이용하여 다양한 대기, 지표, 해양 관련 다양한 정보들을 제공하고 있다(신형진 등, 2010). NASA의 EOS Data Gateway는 MODIS 영상을 비롯하여 EOS 프로그램을 통 해 제작한 다양한 위성영상자료를 대기, 빙하, 육지, 대양, 자료보정 분야별로 제공하고 있다 (박정술 등, 2006). MODIS Data Product 중 지표면반사율(MOD09: Surface Reflectance) 은 $500 \mathrm{~m}$ 공간해상도와 8 일 단위의 합성자료 로서, 7 개의 분광 밴드 자료를 제공 한다 (표 1). 본 연구에서는 태국 짜오프라야 강 유역 을 대상으로 2011년 7월 27일부터 2012년 1 월 9 일까지의 구름의 영향을 최소화 할 수 있는 MOD09 8일 합성 영상을 수집하였다 (그림 3).

\section{TABLE 1. MODIS 밴드 특성}

\begin{tabular}{ccccc}
\hline Primary Use & \multicolumn{2}{c}{ Band } & Bandwidth $(\mu \mathrm{m})$ & Resolution $(\mathrm{m})$ \\
\hline \hline Land/Cloud/Aerosols & 1 & RED & $620-670$ & \multirow{2}{*}{250} \\
\cline { 2 - 4 } Boundaries & 2 & NIR1 & $841-876$ \\
\hline \multirow{3}{*}{ Land/Cloud/Aerosols } & 3 & BLUE & $459-479$ \\
\cline { 2 - 4 } Properties & 4 & GREEN & $545-565$ & \multirow{2}{*}{500} \\
\cline { 2 - 4 } & 5 & NIR2 & $1230-1250$ \\
\cline { 2 - 4 } & 6 & SWIR1 & $1628-1652$ \\
\hline
\end{tabular}




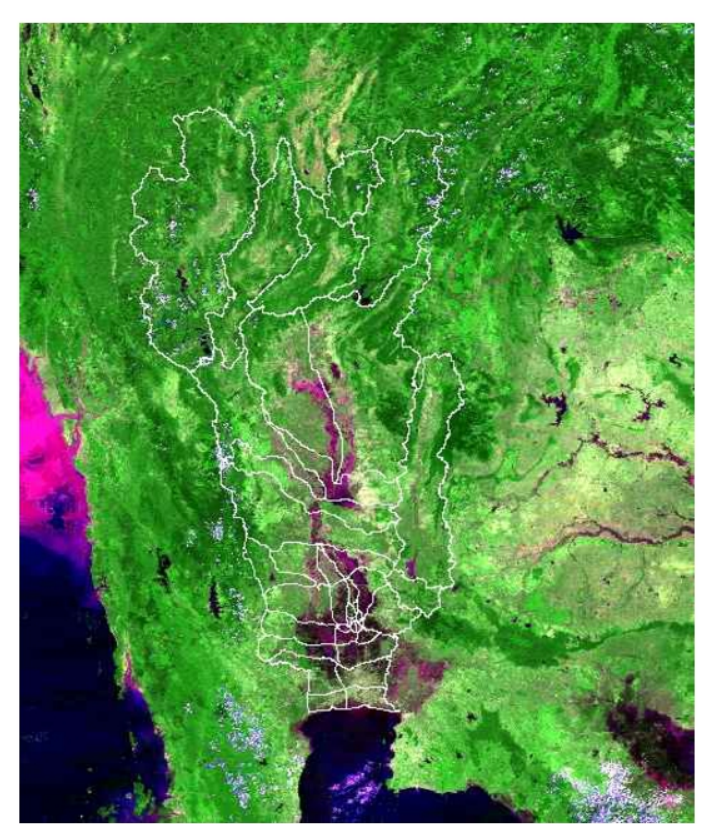

FIGURE 3. Terra MODIS 1, 6, 3번 밴드 합성영상 (2011.11.8)

\section{MODIS 지수}

식생지수는 식생의 분포와 상태를 나타내는 지수이며, 지표면의 식물과 그 외의 물체들에 대한 분광반사특성을 이용하여 식물에 관한 정보를 나타내는 지표이다(신사철과 안태용, 2007). EVI(Enhanced Vegetation Index)는 MODIS Land Discipline Group에서 MODIS 영상자료에 적용하기 위해 개발한 방법으로 (Huete et al., 2002), NDVI(Normalized Difference Vegetation Index)의 개량 식생 지수로서 식물의 반사에 영향을 주는 토양의 반사효과가 분리되고, 토양에 의한 영향은 soil adjustment factor L에 의해 보정이 이 루어지게 되며, 식생이 많은 지역에 대한 민 감도가 개선되고, 대기에 의한 영향은 대기의 산란에 가장 민감한 청색밴드 영상을 추가함 으로써 대기에서 에어로졸 산란에 대한 오차 가 감소된 향상된 식생 모니터링을 가능하게 한다. EVI는 식 (1)과 같은 계산식을 통해 산
출할 수 있다.

$$
E V I=2.5 \times \frac{N I R-R E D}{N I R+6 \times R E D-7.5 \times B L U E+1}
$$

여기서, NIR : 근적외선 밴드의 지표면 반 사율

$\mathrm{RED}$ : 적색 밴드의 지표면 반사율 BLUE : 청색 밴드의 지표면 반사율

지표수분지수(LSWI: Land Surface Water Index)는 근적외선밴드와 중적외선 밴드의 조 합으로 계산되며(식 2), 식생 수분 함량 및 토양 수분 함량에 민감하게 반응한다 (Tucker, 1980). 근적외선 영역의 반사특성 과 중적외선 영역의 반사특성을 이용하여 수 관층의 수분함유량을 추정하는데 효과적으로 활용가능하다(Xiao et al., 2002; 박정술 등, 2006). 수분부족으로 인한 식생지수의 반응 이 일정한 지체시간을 갖는 반면, LSWI는 지 표면의 수분 함유량 정보를 신속하게 제공하 므로 지표면 수분변화를 파악하는데 활용할 수 있다 (Xiao et al., 2005; Peng et al., 2011).

$$
L S W I=\frac{N I R-S W I R}{N I R+S W I R}
$$

여기서, NIR : 근적외선 밴드의 지표면 반 사율

SWIR : 중적외선 밴드의 지표면 반사율

EVI는 식생피복의 상태를 나타내고, LSWI 는 식생과 수분의 정보와 혼합되어있다. MODIS LSWI가 EVI 보다 큰 시기를 논지역 의 담수 시기라고 판단하였다(식 3). Xiao et al. (2002)는 중국 5개 연구지역에 SPOT-4 Vegetation (VGT) 센서를 이용하여 알고리 듬을 검증하였다. DVEL (Difference Value 
between EVI and LSWI)은 식 (3)과 같이 식생과 토양수분에 반응하며 식생피복의 영향 을 줄이고, 지표수분을 안정적으로 추정할 수 있다(Xiao et al., 2005; Xiao et al., 2006).

$$
\begin{aligned}
& L S W I \geq E V I \\
& D V E L=E V I-L S W I
\end{aligned}
$$

본 연구에서는 대상유역에 대하여 2011년 7월 27일부터 2012년 1월 9일까지 EOS Gateway를 통해 수집한 MODIS product MOD09 Surface Reflectance 8일 합성영상 을 수집한 후 MODIS Reprojection Tool을 이용하여 WGS84 UTM48N 좌표체계로 변환 하고 자료를 이용해 밴드 연산을 통하여 EVI, LSWI, DVEL을 각각 구축하였다(그림 4).

\section{Terra MODIS를 이용한 홍수 범람지역 추출 알고리듬}

Xiao et al.(2005)과 Sakamoto et al. (2007)에 의해 제안된 홍수범람지역 탐지 알 고리듬을 기반 EVI와 DVEL의 임계값을 이용 하여 Flood 지역과 Non-flood 지역을 추출 하였다. 일반적으로 식생이 분포한 픽셀에서 LSWI는 EVI에 비해 낮은 값을 갖는다. 하지
만 식생픽셀이 침수되년 지표의 수분함량이 높아지기 때문에 LSWI는 EVI보다 높은 값을 갖게 된다. $\mathrm{EVI}$ 는 지표수분 지역을 결정짓는 중요 인자이다. Xiao et al.(2005)은 선행연 구를 토대로 LSWI가 EVI 보다 크년 범람이 라고 판단하고 홍수 범람지역 탐지 알고리듬 을 구축하였으며, Peng et al.(2011)은 EVI 임계값을 활용한 간단한 조건으로 강과 호수 에서의 EVI 값을 구축하였다. 강과 호수에서 는 EVI가 낮은 반면 그 외 논, 산림지역에서 의 EVI 값이 높게 나타난다. 따라서 강과 호 수등 육지내 담수 자료(그림 1)를 이용하여 연구기간동안의 $\mathrm{EVI}$ 의 임계값을 추출하였다. Yan et al.(2010)은 EVI 값을 0.2 이하, Sakamoto et al.(2007)은 0.3 이하, Peng et al.(2010)은 0.55 이하, 정승택 등 (2011) 은 0.35 이하이면 수역이라고 분석하였다(표 2). 그림 6 에서와 같이 연구기간동안의 수역 에서의 $\mathrm{EVI}$ 의 최고값은 0.24 이며, 평균 수역 $\mathrm{EVI}$ 는 0.15 인 것으로 분석되었다. 본 연구에 서는 $\mathrm{EVI}$ 임계값을 $0.2,0.25,0.3$ 적용해보 았으며, 그 결과 태국 짜오프라야 강 유역의 적정 임계값은 0.2 인 것으로 나타났다. 보편 적으로 LSWI는 EVI와 유사한 경향을 나타낸 다. 수분은 온도와 식생의 성장에 의해 결정 되기 때문이다. DVEL은 식생과 토양수분의

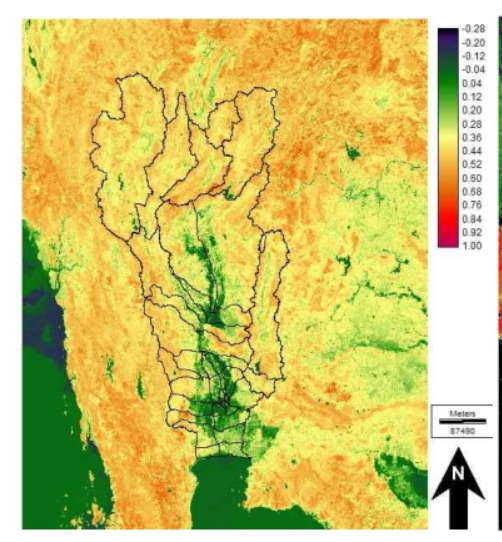

(a)

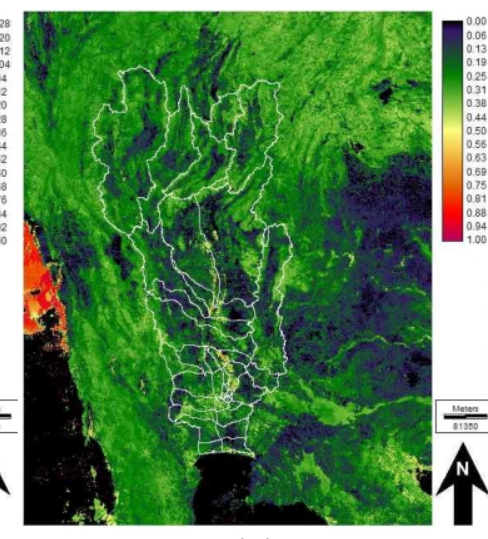

(b)

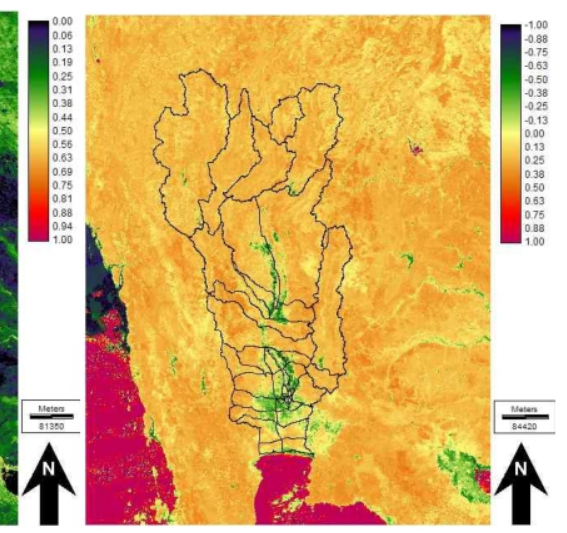

(c)

FIGURE 4. 대상유역의 (a) EVI, (b) LSWI, (c) DVEL (2011.11.08) 


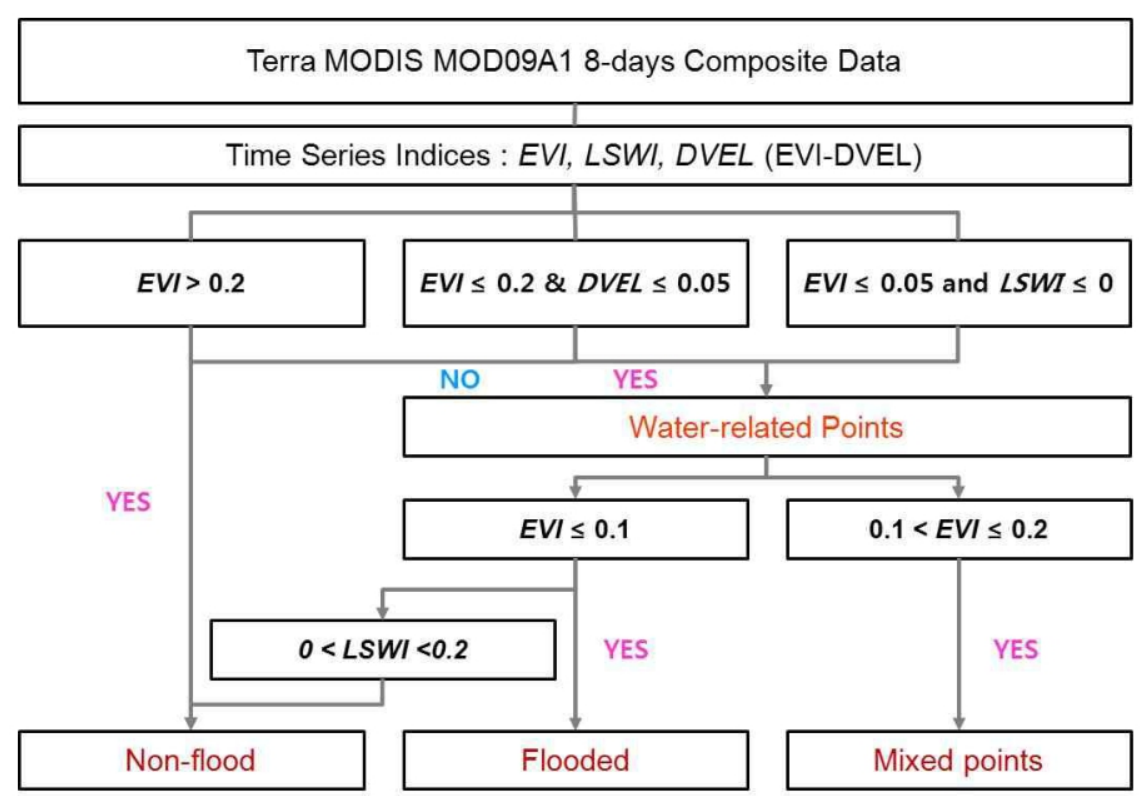

FIGURE 5. 홍수범람지역 추출 알고리듬

영향을 받는다. 토지피복이 수역일 때 DVEL 의 값은 0 보다 작을 것이다. 이는 $\mathrm{EVI}$ 가 LSWI 보다 작을 때 나타난다. Xiao et al. (2005; 2006)은 DVEL 값이 수역과 비수역 을 구분하는 주요인자임을 연구를 통해 제시 하였으며, DVEL 값이 0.05 보다 작으면 수 역관련 픽셀이라고 제시하였다(식 5,6 ). 하 지만 Sakamoto et al.(2007)에 의하면 호수 나 바다는 DVEL 값이 항상 0.05 이하인 것 은 아니라고 분석되었다.

$$
\begin{aligned}
& L S W I+0.05 \geq E V I \\
& D V E L(E V I-L S W I) \leq 0.05
\end{aligned}
$$

높은 DVEL 값은 수역의 NIR 밴드 값이 극히 낮은 반사율(거의 0)에 가깝기 때문이 다. 따라서 EVI가 0.05보다 작고 LSWI가 0
이하 이면 수역이라고 분석하였다.

수역관련 픽셀은 다음과 같은 간단한 방법 을 기반으로 두 가지 항목(홍수지역과 혼합지 역)으로 나누었다. EVI는 큰 호수와 바다처럼 균질한 수역에서 혼합(물, 식물, 토양의 혼합) 픽셀에서보다 일반적으로 낮은 값을 갖는다. 그러므로 $\mathrm{EVI}$ 는 수역관련 픽셀의 홍수지역과 혼합지역 사이의 구분 기준으로 이용될 수 있 을 것으로 판단된다. EVI가 0.1 이하년 홍수 지역이고, EVI가 0.1 보다 크고 0.2 이하면 혼합지역으로 정의하였다(그림 5).

\section{결과 및 고찰}

\section{1. 수역 내의 MODIS 지수 결과}

강과 호수 등 육지 내 수역 자료(그림 1)를 이용하여 2011년 7월 27일부터 2012년 1월

TABLE 2. $E V I$ 의 식생, 수역 결정 임계값

\begin{tabular}{cccccc}
\hline 임계값 & Yan et al.(2010) & Sakamoto et al.(2007) & Peng et al. (2010) & 정승택 등(2011) & 본 연구 \\
\hline \hline EVI & 0.2 & 0.3 & 0.55 & 0.35 & 0.2 \\
\hline
\end{tabular}




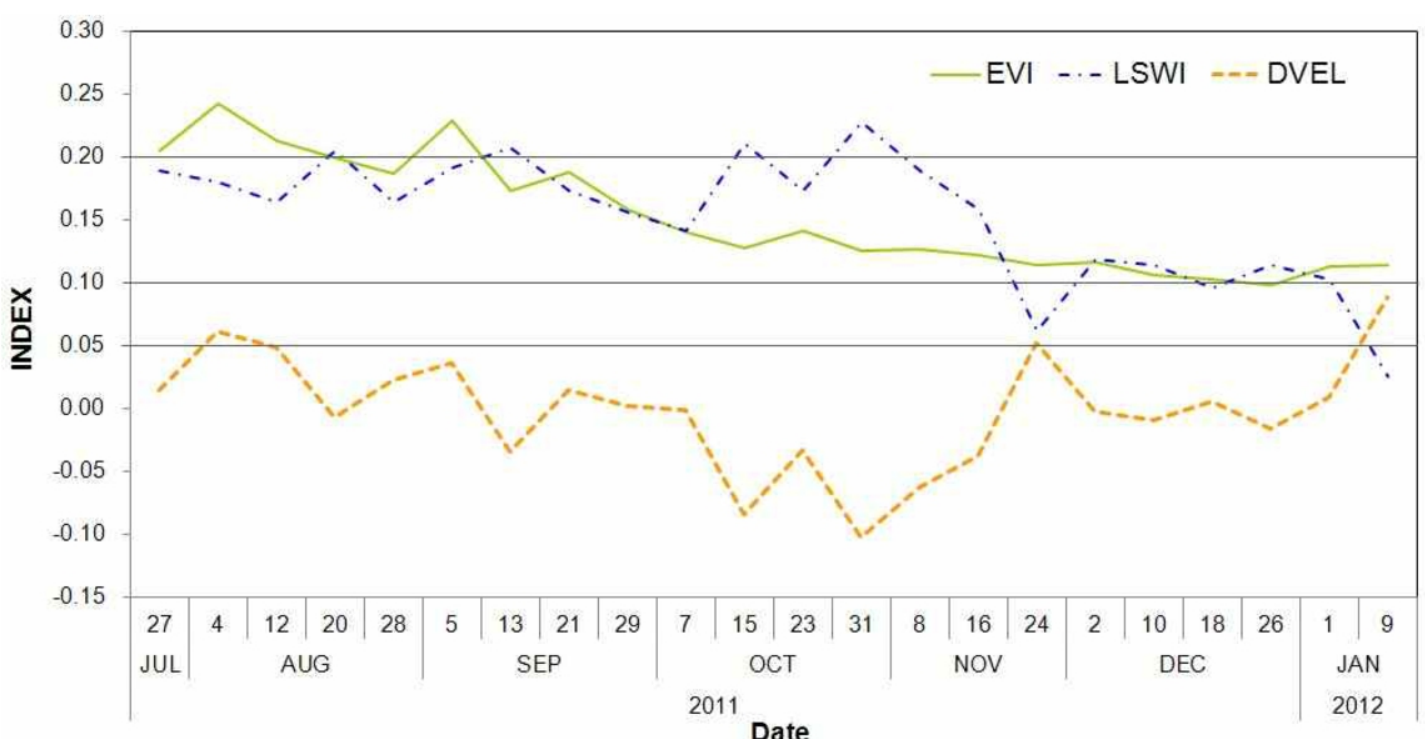

FIGURE 6. 담수지역의 평균 EVI, LSWI, DVEL 지수

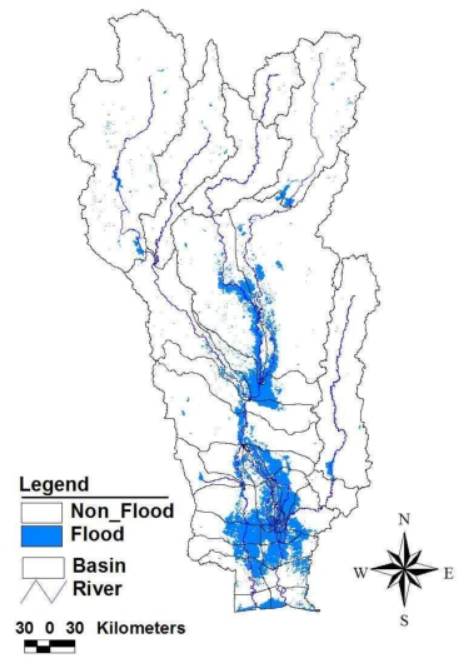

(a) Water-related area

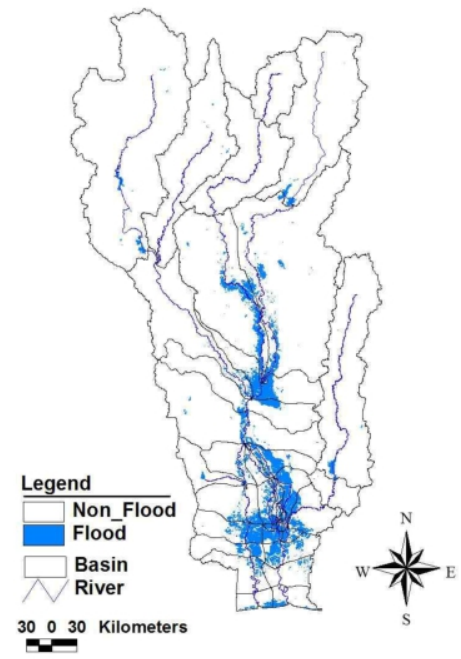

(b) Flooded area

FIGURE 7. Terra MODIS로부터 추출된 수역 지역 (a) 홍수 지역 (b) 분포도 (2011.11.8)

9일까지의 평균 EVI, LSWI와 DVEL 지수 값을 추출하였다(그림 6). 그 결과 전체기간 동안 평균 $\mathrm{EVI}$ 는 0.15 , LSWI는 0.15 그리고 DVEL은 0.0으로 분석되었다. 태국 홍수의 시 작 지점인 북서쪽 난강 침수범람 기간인 2011년 7월 27일부터 2011년 9월 5일까지
의 EVI는 0.21, LSWI는 0.18, DVEL은 0.03 이었다. 이는 북부 지역만 침수된 상황이 므로 남부지역의 수역은 식생의 영향으로 식 생지수가 전체평균보다 큰 값임을 확인할 수 있다. 짜오프라야 강 유역의 전체 홍수범람이 최대였던 2011년 10월 15일부터 2011년 10 


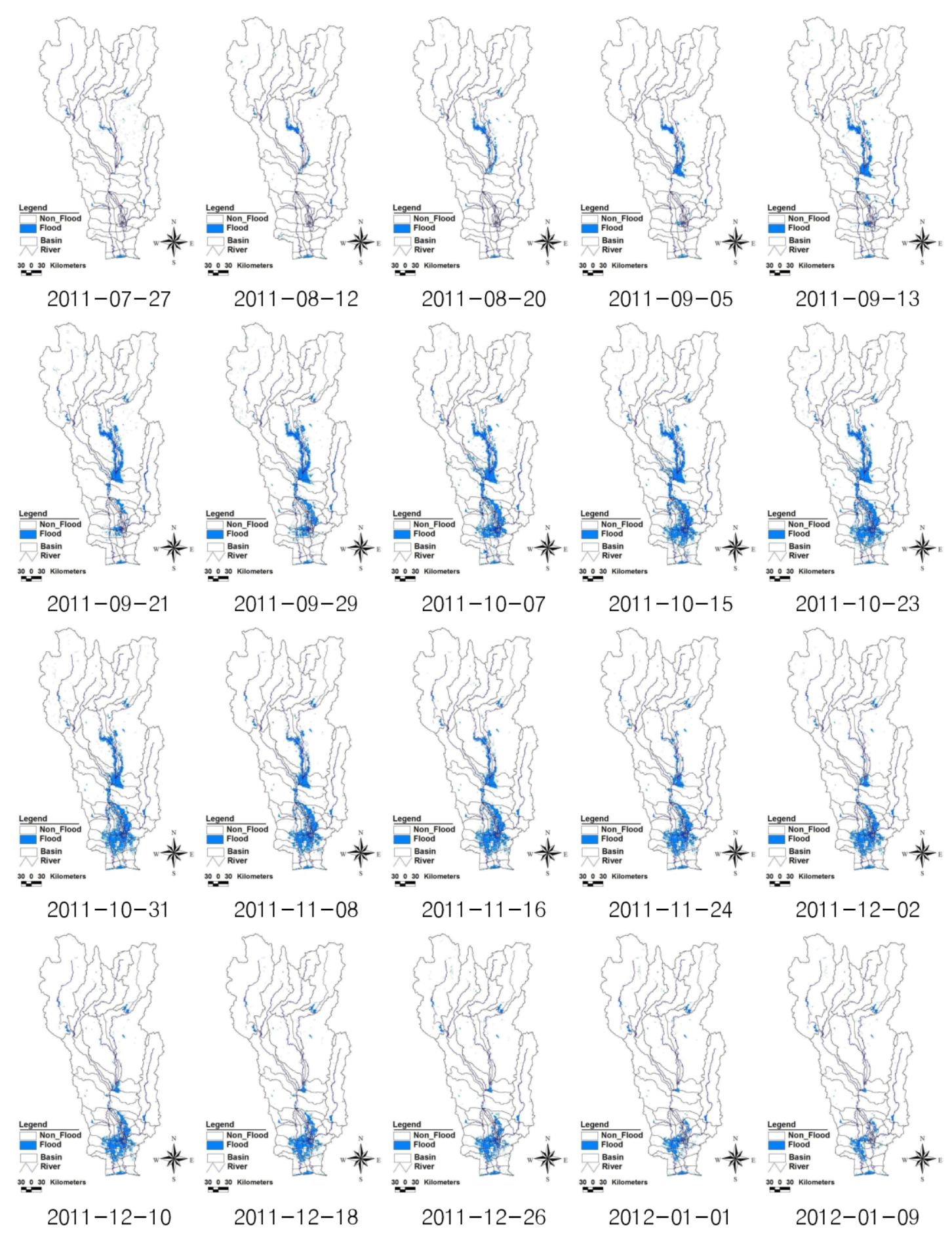

FIGURE 8. Terra MODIS flooded area 


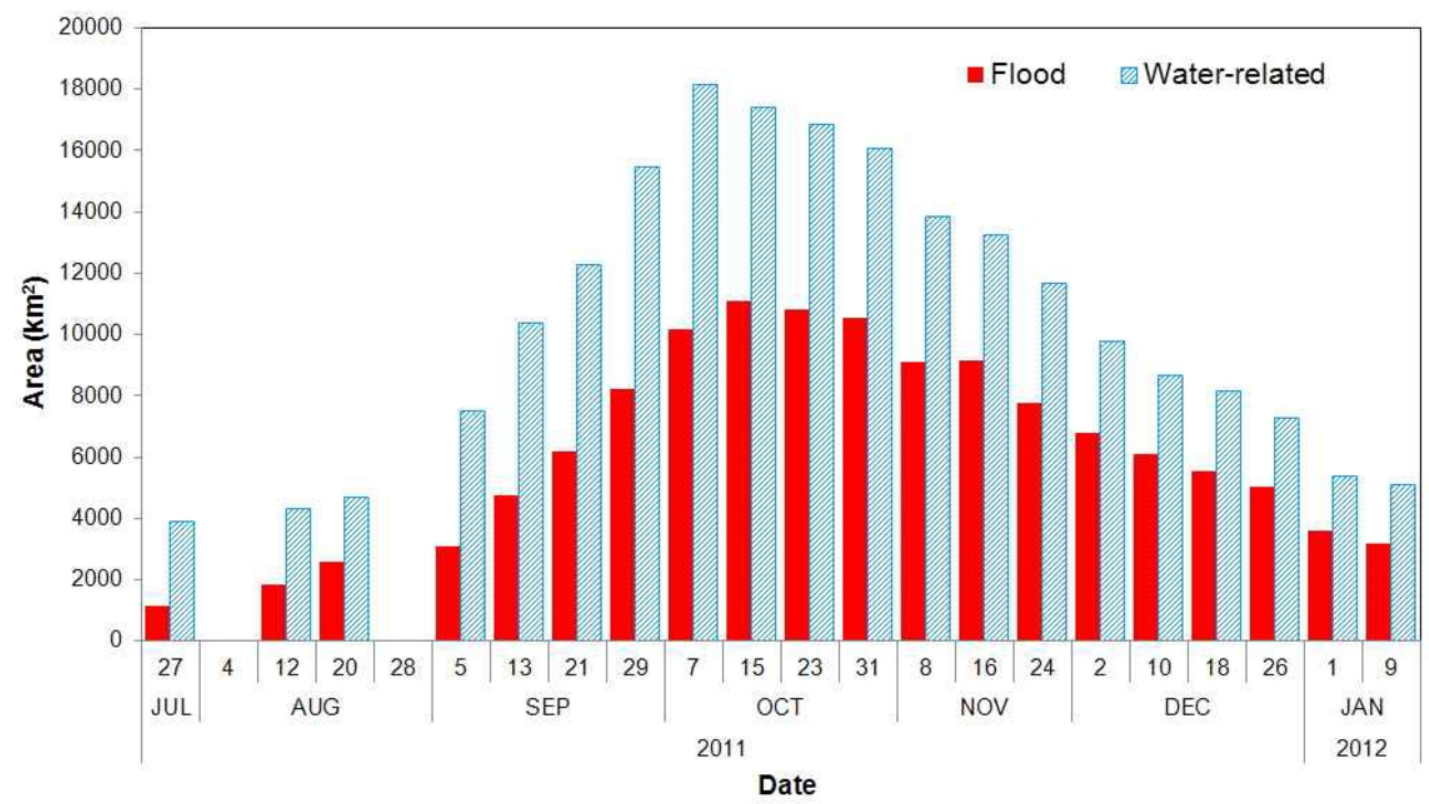

FIGURE 9. Terra MODIS로부터 추출된 수역과 홍수범람 면적 비교

월 31 일까지의 EVI는 0.13, LSWI는 0.20, DVEL은 -0.07 로 LSWI가 EVI보다 확연히 큰 것을 알 수 있으며, 식생지수가 전체평균 보다 작은 값을 갖는데 이는 홍수범람에 의해 혼합지역이 침수된 것으로 확인할 수 있다.

\section{Terra MODIS 홍수범람지역 추출 결과}

Terra MODIS 위성영상과 홍수범람지역 추출 알고리듬을 이용하여 2011년 7월 27일 부터 2012년 1월 9일까지 추출한 수역관련지 역 (그림 7)과 혼합지역을 제거한 홍수지역 (그 림 8)을 살펴보년 2011 태국 홍수는 짜오프 라야 강 상류인 북동쪽의 난강의 홍수범람을 시작으로 2011년 9월 5일 태국 중앙부의 짜 오프라야 강 중부지역의 침수범람을 확인할 수 있다. 2011년 10월 7일 분석 영상을 보년 북서쪽 핑강의 범람도 확인할 수 있다. 홍수 는 2011년 10월 7일부터 2011년 12월 2일 까지 극심한 것으로 나타났으며 2011년 10월 15일부터 2011년 10월 31일에 최대 홍수범 람이 발생하였다. 대상유역의 북동쪽 난강의
홍수는 2011년 11월 16일부터 배수되어 2012년 1월 1일에는 거의 배수가 완료된 것 을 확인할 수 있었다. 2012년 1월 9일 짜오 프라야 강 하류부 저지대 지역의 배수가 천천 히 진행되는 것을 확인할 수 있다(그림 9).

구축된 홍수지역과 수역관련지역의 면적을 살펴보면 최대 면적은 유역면적 $\left.(160,813 \mathrm{~km})^{2}\right)$ 의 각각 $6.9 \%, 11.3 \%$ 이고, 최대 홍수범람 기 간이었던 2011년 10월 15일부터 2011년 10 월 31 일에 평균 범람년적이 각각 $6.7 \%$ $\left(10,823 \mathrm{~km}^{2}\right), 10.4 \%\left(16,753 \mathrm{~km}^{2}\right)$ 로 침수된 것 으로 분석되었다. 그림 9 와 같이 2011년 10 월 15 일부터 배수가 시작되어 침수면적이 감 소되는 것을 확인할 수 있다.

\section{요약 및 결론}

본 연구에서는 태국의 홍수 범람 유역인 짜 오프라야 강 유역을 대상으로 식생지수와 지 표수분지수를 이용한 홍수범람지역 탐지 알고 리듬을 기반으로 Terra MODIS 위성영상을 
이용하여 짜오프라야 강 유역의 홍수범람 탐 지 기법을 제시하고, 홍수범람지역을 구축하 여 침수피해지역의 공간적 범위를 분석하고자 하였다. 본 연구를 통해 얻어진 결론은 다음 과 같다.

첫째, 2011년 대홍수로 침수가 일어난 태 국 짜오프라야 강 유역을 대상으로 2011년 7 월 27일부터 2012년 1월 9일까지의 Terra MODIS MOD09 합성영상을 수집하고 밴드 연산을 통하여 식생지수인 EVI, 지표수문지수 인 LSWI와 DVEL를 각각 구축하였다.

둘째, Xiao et al.(2005)과 Sakamoto et al. (2007)에 의해 제안된 홍수범람지역 탐지 알고리듬을 기반으로 EVI와 DVEL의 임계값 을 이용하여 Flood 지역과 Non-flood 지역 을 추출하였다. 임계값은 $\mathrm{EVI} 0.2, \mathrm{DVEL}$ 0.05 를 각각 적용하였으며, 수역과 관련하여 홍수지역과 혼합지역을 구분하는 임계값은 EVI 0.1을 적용하여 구축하였다.

셋째, 강과 호수 등 육지 내 담수 자료를 이용하여 2011년 7월 27일부터 2012년 1월 9일까지의 평균 EVI, LSWI와 DVEL 지수 값을 추출한 결과 전체기간 동안 각각 0.15 , $0.15,0.0$ 으로 분석되었으며, 짜오프라야 강 유역의 전체 홍수범람이 가장 크게 발생했던 2011년 10월 15일부터 2011년 10월 31일 까지 각각 $0.13,0.20,-0.07$ 로 LSWI가 EVI보다 확연히 큰 것을 알 수 있었다.

넷째, 구축된 홍수지역과 수역관련지역의 면적을 살펴보면 최대 면적은 유역면적 $\left(160,813 \mathrm{~km}^{2}\right)$ 의 각각 $6.9 \%, 11.3 \%$ 이고, 최대 홍수범람 기간이었던 2011년 10월 15일부터 2011년 10월 31일에 평균 범람면적이 각각 $6.7 \%\left(10,823 \mathrm{~km}^{2}\right), 10.4 \%\left(16,753 \mathrm{~km}^{2}\right)$ 침수된 것으로 분석되었다. 향후 정량적인 홍수범람 량 평가를 위한 위성영상의 홍수범람지역 추 정 기법의 기본 자료로 유용하게 사용될 것으 로 기대되며 홍수 피해 지역의 신속한 복구를 위한 다양한 의사결정 자료를 제공할 수 있을 것으로 사료된다. $\overline{\underline{\underline{\text { kAGIS }}}}$

\section{참고문헌}

박병욱, 김철. 1997. 원격탐사 자료를 이용한 자연재해분석에 관한 연구. 한국측지학회지 $15(2): 237-244$.

박정술, 김경탁, 이진희, 이규성. 2006. 봄 가 뭄 평가를 위한 다중시기 MODIS 영상의 적 용성 분석. 한국지리정보학회지 9(4):176192.

세계일보. 2011.10.30. 방콕 '완전수몰' 최 악 상황 넘겼지만... 커져가는 물폭탄 재앙. 정진수 기자.

신사철, 안태용. 2007. 인공위성 자료를 활용 한 광역증발산량의 산정방법 개발. 한국지리 정보학회지 10(2):70-80.

신사철, 유철상. 1997. NOAA/AVHRR 자료를 이용한 순일차생산량 분포 추정. 한국환경과 학회지 6(6):605-612.

신형진, 하림, 박민지, 김성준. 2010. MODIS NDVI와 Morton 증발산량의 관계를 이용한 공간증발산량 산정 기법 연구 - 충주댐유역 을 대상으로-. 한국농공학회논문집 52(1): 19-24.

이규성, 김양수, 이선일. 2000. 시계열 위성레 이더 영상을 이용한 침수지 조사. 한국수자 원학회논문집 24(5D):823-828.

이미선, 박근애, 김성준. 2006. RADARSAR $\mathrm{SAR}$ 영상을 이용한 농촌지역 소하천주변의 침수피해지역 추정 연구. 한국수자원학회논 문집 39 (11):969-976.

정승택, 장근창, 홍석영, 강신규. 2011. MODIS 영상자료를 이용한 관개시기 탐지와 논 피복지도 제작. 한국농림기상학회지 $13(2): 69-78$.

채효석. 2005. 원격탐사와 GIS를 이용한 Tonle Sap호의 홍수량 평가. 한국지리정보 학회지 8(3):96-106. 
Huete, A.R., K. Didan, T. Miura and E. Rodriguez. 2002. Overview of the radiometric and biophysical performance of the MODIS vegetation indices. Special Issue Remote Sensing of Environment 83:195-213.

Peng, D., A.R. Huete, J. Huang, F. Wang and H. Sun. 2011. Detection and estimation of mixed paddy rice cropping patterns with MODIS data. International Journal of Applied Earth Observation and Geoinformation 13(1):13-23.

Sakamoto, T., N.V. Nguyen, A. Kotera, H. Ohno, N. Ishitsuka and M. Yokozawa. 2007. Detecting temporal changes in the extent of annual flooding within the Cambodia and the Vietnamese Mekong Delta from MODIS time-series imagery. Remote Sensing of Environment 109(3) :295-313.

Tucker, C.J. 1980. Remote sensing of leaf water content in the near infrared. Remote Sensing of Environment 10:23-32.

Xiao, X., S. Boles, J.Y. Liu, D.F. Zhuang, S. Frolking, C.S. Li, W. Salas and B. Moore. 2005. Mapping paddy rice agriculture in sounthern China using multi-temporal MODIS images. Remote Sensing of Environment 95(4):480-492.
Xiao, X., S. Boles, S. Frolking, C.S. Li, J.Y. Bau, W. Salas and B. Moore. 2006. Mapping paddy rice agriculture in South and southeast Asia using multitemporal MODIS images. Remote Sensing of Environment 100:95-113.

Xiao, X., S. Boles, S. Frolking, W. Salas, B. Moore and C. Li. 2002. Observation of flooding and rice transplanting of paddy rice fields at the site to landscape scales in China using VEGETATION sensor data. International Journal of Remote Sensing 23:3002-3009.

Yan, Y.E., Z.T. Ouyang, H.Q. Guo, S.S. Jin and B Zhao. 2010. Detecting the spatiotemporal changes of tidal flood in the estuarine wetland by using MODIS time series data. Journal of Hydrology $384(1-2): 156-163$

Zhan, X., R.A. Sohlberg, J.R.G. Townsehend, C. DiMiceli, M.L Carroll, J.C. Eastman, M.C. Hansen and R.S. DeFriesa. 2002. Detection of land cover changes using MODIS $250 \mathrm{~m}$ data. Remote Sensing of Environment 83(12):336-350.

위키백과. 짜오프라야강. http://ko.wikipedia org/wiki.

태국 기상청. http://www.tmd.go.th/en. $\underline{\underline{\underline{\mathbf{k A G S}}}}$ 